\title{
The Personality of Manipulator in Translation
}

\author{
Natalya V. Klimovich* \\ Siberian Federal University \\ 79 Svobodny, Krasnoyarsk, 660041, Russia
}

Received 22.07.2015, received in revised form 12.08.2015, accepted 14.09.2015

The research paper is concerned with the problem of manipulation in translation. Analyzing the reasons for manipulation, the author is mainly focuses on the issue of who/what influences manipulation in translation. Through the concept of "initiator" and two types of manipulation in translation, the author makes an attempt to introduce reasoning of the concept of "manipulator" in translation and define a person/phenomenon that is consciously or unconsciously responsible for manipulation or determines it.

Keywords: initiator, manipulator, literary text, conscious manipulation, unconscious manipulation.

DOI: 10.17516/1997-1370-2015-8-12-2861-2867.

Research area: philology.

\section{Introduction}

The concept of manipulation in translation introduces an idea, shared initially by the Manipulation School representatives (S. Bassnett, T. Hermans, J.S. Holmes, I. EvenZohar, A. Lefevere, G. Toury), and later by professional translators and modern scholars (F. Farahzad, N.G. Kornaukhova, P. Kuhiwczak, N.V. Klimovich) that both translators and readers are manipulated. It is pointed out that from the point of view of the target literature, all translation implies a degree of manipulation of the source text for a certain purpose and translation is regarded as a result of manipulation of the source text which is governed by the target culture and can not be avoided.

Manipulation in literary translation is widely studied both by international and Russian researches, but still there are some areas that require thorough study. One of them is why translator changes the original text, is it his/her ignorance or somebodies' influence, and who acts as a manipulator in each case?

\section{Point of View}

There is a common conviction that we are being manipulated and influenced through television, mass media and internet. R. Holiday, the Forbes journalist (Holiday, 2012), who calls himself media manipulator, states that manipulation currently shapes everything we read, hear and watch online, thus, manipulation is the status quo. Based on the example of media manipulation he writes that today the media driven by blogs - is assailed on all sides, by the crushing economics of their business, dishonest

(C) Siberian Federal University. All rights reserved

* Corresponding author E-mail address: klimovich7979@mail.ru 
sources, inhuman deadlines, pageview quotas, inaccurate information, greedy publishers, poor training, the demands of the audience, and so much more, and line between the real and the fake becomes indistinguishable. "Manipulators on both sides of the equation - the writers and the marketers and press agents - all influencing the news to their own benefit" (Holiday, 2012).

But media manipulation is directly linked to political manipulation, or manipulation for the benefits of the ruling elite. R.B. Absattarov (2012) believes that mass media represents the greatest danger to the citizens as a tool of political manipulation - hidden management of people's political consciousness and behavior to force them to operate or stay idle contrary to own interests. Political bodies always use mass media for "planting" the stereotypes, favorable to the authorities. In a course of such a manipulating influence, a person doesn't feel external compulsion, it seems that it is the person him/herself who makes a decision and chooses the form of behavior.

Nowadays researches also focus their attention on manipulation in translation which is studied by many scholars both Western and Russian. The Manipulation School of translation studies, influenced by the works of G. Toury, J.S. Holmes and I. Even-Zohar, first appeared in the 1980s. The anthology of essays "The Manipulation of Literature" edited in 1985 by T. Hermans (Hermans, 1985) gave name to the "Manipulation School". The group of contributing scholars tried to show that translations, "rather than being a secondary and derivative genre, were instead one of the primary literary tools that larger social institutions - educational systems, art councils, publishing firms, and even government - had at their disposal to 'manipulate' a given society in order to 'construct' the kind of 'culture' desired" (Bassnett, 2000, p. x). It is stated that churches would commission Bible translations; government would support national epic translations; schools would teach great book translation; kings would be patrons for heroic conquests translations; socialist regimes would underwrite socialist realism translations.

Initially, the ideas of the Manipulation School in translation mostly concerned literary translation, but the focus shifted from written to oral and non-literary translation. Understanding translation as socially contexted behavioral type of activity, the Manipulation School rejects the idea that the target text is faithful reproduction of the source text, but sees translation as a manipulation of the source text for a certain purpose and heavily draws on sociology and cultural studies, claiming that translation is manipulation, thus, it is unavoidable. A. Ducate considers manipulation in translation as "the translators/interpreter's handling of a text which results in the adaptation of the text for the Target Audience, considering the cultural, ideological, linguistic and literary differences between the cultures in contact, which takes place within a particular cultural setting and is carried out by a human agent, with the consequence of a possible influence of individual- or psychologyrelated factors upon the end product" (Dukate, 2007, p. 5). Accordingly, in literary translation manipulation cannot be avoided as it always will be permeated with various sorts of ideology, and the translator will be compelled to somehow avoid or demonstrate the clashes with dominating target culture norms.

A. Lefevere (1992) states that the dominant role in defining translation policy belongs to ideological considerations. Thus, during certain periods of history some texts were not translated at all or had to be translated according to the certain requirements. One of the best examples is the translation policy adopted by the Soviet Union, where a lot of books that didn't comply with the adopted ideology were not translated at 
all, or translated with numerous omissions and alterations (Klimovich, 2015). In this case we speak about political manipulation, which general technology is based on regular introduction of sociopolitical myths - illusory ideas confirming certain values and norms, thus, people don't suspect about occurring manipulation.

The example of such myths in the communist system included myths about private property as about the main source of sociopolitical harm and the conflict; about inevitability of capitalism collapse and communism celebration, about a supervising role of working class and its communist party as well as about the unique true - the political doctrines of MarxismLeninism (Absattarov, 2012). In the USA, according to American professor H. Schiller (1973), five sociopolitical myths acted as the main ideas confirming domination of the ruling elite: 1) about individual freedom and a personal choice of citizens; 2) about a neutrality of the major political institutes: the congress, the court, the presidential power, and mass-media; 3 ) about invariable egoistical human nature, its aggression, propensity to moneymaking and consumption; 4) about the absence of social conflicts, operation and oppression in the society; 5) about pluralism of mass-media which actually, despite their abundance, are supervised by large advertisers and the government and represents the uniform industry of illusory consciousness.

A. Lefevere (1992) emphasizes two general constrains that influence translators a translator's own (conscious or unconscious) ideology and "the poetics" dominant in the target culture, i.e. the combination of literary devices, genres, motifs, prototypical characters, situations and symbols. F. Farahzad (1998) and G. Toury (1980) believe that translators' behaviour is influenced by a multitude of variables, including not only age, gender or previous experience in translation (i.e. translator's linguistic personality
(Toury, 1980), but also the position of translation within a particular culture, and the more peripheral the position is, the more translation will accommodate itself to the established models. Besides, a translator is trapped between the desire to produce a translation as close to the original text as possible and the desire to comply with the dominant requirements.

A. Kramina (2004) distinguishes two types of manipulation - conscious and unconscious. Manipulation in translation that takes place due to various ideological, economic, social, political and cultural reasons happens consciously; manipulation that happens due to ignorance of a translator is termed unconscious manipulation. Unconscious manipulation is mostly a psychological phenomenon, and occurs under the influence of psychological factors. Thus, A. Kramina writes that "the translator, striving to produce a text acceptable for the target community, has to manipulate between the various constrains under the influence of the political and literary power structures in a given society" (Kramina, 2004 , p. 37), i.e. the translator is influenced by the culture of the target language.

Thus, literary translators deal with cultures. It is cultural knowledge coming from a thorough familiarity with a culture in which a language is spoken, rather than mere mastery of language. "Any literary translator frequently encounters reminders of the difference between knowing the language and knowing the culture" (Landers, 2001, p. 73]. Admittedly, it is sometimes difficult to distinguish between incomplete proficiency in the source language and insufficient knowledge of that language culture. According to C.E. Landers (2001) biculturality is an important quality for the translator. He distinguishes bicultural from the bilingual individual by the fact that bicultural has internalized certain elements of the two cultures to which the merely bilingual are unlikely to ever be exposed. But there is a factor that contributes 
manipulation in translation: "quite often many readers do not really care that much whether the book they are reading is a translation or not. ... and in most cases readers of translations are monolingual, and will not compare the translation with the original" (Kuhiwczak, 2006, p. 116).

One of the important questions concerning manipulation in translation is why would a translator misunderstand and distort the original text and who in this case acts as a manipulator? Who is "skillful at getting what they want by cleverly controlling or deceiving other people"? (Longman Dictionary..., 2005, p. 1001).

C. Nord (2006) introduces the concept of initiator who plays a crucial role in the process of translation. Apart from being an individual having his/her own personal characteristics, the initiator is the factor that starts the process and determines its course. The process of intercultural text transfer is started because the initiator wants a particular communicative instrument: the target text. This implies that the initiator wants the translation for a certain purpose. The reception of the target text by the initiator or any other person the target text is passed on depends on this person. It is the purpose that determines the requirements to be met by the translation. Although the initiator is the only one who actually defines the target text scopos, the responsibility for the translation will always rest with the translator. Thus, it is the translator, as an expert in the target culture, who converts the information provided by the initiator, and it is the translator alone who has the competence to decide whether the translation which the initiator asks for can actually be produced on the basis of the given source text, and, if so, by which procedures and techniques this should be best done. On the basis of the functional approach it is determined that it is "not the source text as such, or its effect on the source text receiver, or the function assigned into it by the author, that operates the translation process, as is postulated by equivalence-based translation theory, but the intended function, or scopos of the target text as determined by the initiator's needs" (Nord, 2006, p. 10).

Thus, the translator's reception is determined by the communicative needs of the initiator. In practice, translators usually receive instructions before they start reading the source text. Therefore, the reception process will inevitably be influenced by this knowledge, even though they may do their best to approach the text in as unbiased way as possible. Accordingly, the initiator who activates the process of translation determines the translator's behavior and influences it, thus might act as the manipulator.

R.B. Absattarov (2012) identifies two main models the manipulator uses for manipulating individuals: psychological and rational. The basic characteristic of the first model is use of automatic reaction of the individual or other psychological stimulus. "The essence of manipulation consists in this case in a choice of the most suitable stimulus for actuating those psychological mechanisms which are capable to cause reaction desirable for the manipulator" (Absattarov, 2012). In rational model the manipulation is carried out not through the usage of psychological motives, and by the means of a deceit and/or perfidy. Among the forms of a manipulation carried out according to this model, the following were allocated: reduction of volume of the information accessible to the ordinary citizen; propagation use, i.e. granting to citizens partly true, but the tendentious information; privacy use, i.e. deliberate concealment of the information which is capable to undermine an official political policy; information overload, i.e. conscious granting of the excessive information on purpose to deprive an ordinary citizen of possibility to acquire and estimate it truly and adequately. The essence of such approach consists in difficulty for individuals of actual access to the information that forces 
them to rely on its official interpretation. As for conscious manipulation in translation, that takes place due to political reasons, in most cases it is rational model of manipulation that is used by the manipulator to influence/control the translator.

Understanding manipulation as conscious or unconscious influence on a viewer/reader, we intentionally change the definition given by N.G.Kornaukhova, whounderstandsmanipulation as "conscious or unconscious influence on a viewer/reader by a translator" (Kornaukhova, 2011, p. 180), as it means that in both conscious and unconscious manipulation translator is the manipulator. In the opinion of the author of this research paper, wholwhat acts as a manipulator, depends on the type of manipulation.

In the case of unconscious manipulation, it is translator who acts as manipulator, changing the meaning of the source text. According to A. Pym (2006) there is a common agreement that translators belong to one culture only - the target culture. Similarly to L. Venuti, A. Lefevere refers to translators as remaining "within the boundaries of the culture that is theirs by birth or adoption" (Lefevere, 1992, p. 13), thus, the target culture. If the translator works within the target culture, he/she mostly domesticates the foreign text, thus, sometimes, the translator acts as the manipulator unintentionally, only due to the lack of linguistic and/or cultural knowledge.

In the case of the aforementioned media manipulation, when the author intentionally produces the text with the aim to manipulate the recipients, the author acts as a manipulator of the original text. The translator under these circumstances turns into unconscious manipulator, as the text he/she produces will manipulate the recipients of the target language as well, but the translator does it unconsciously, he/she just reproduces the original text that has manipulative function.
But in case of conscious manipulation the process appears to be more complicated. Under these circumstances, the translator is influenced/ manipulated as well. The question is: By whom? In some cases, as it was found out, by the initiator of translation, as initiator turns into manipulator, as this person or institution uses his/her power/ influence to control or influence the process. To manipulate translators the initiator has the following motivations, identified by H.B. Braiker (2004):

- the need to advance his/her own purposes and personal gain;

- a want and need to feel in control;

- a desire to gain a feeling of power over others.

But is it only initiator who manipulates the recipients of translation? The translator's command of the source culture and target culture allows anticipating the possible reaction of the text receiver and thereby verifying the functional adequacy of the translation they produce. What is important when we talk about conscious manipulation is the fact that the translator is the text- producer in the target culture who adopts somebody else's intentions in order to produce a communicative instrument for the target culture. The initiator's aims and intensions are mostly connected with cultural norms and political situation in a country. Thus, in different countries of the world in different periods some fictional texts were not translated at all, or were translated according to definite requirements. One of the examples is translation policy adopted in the Soviet Union, when, due to the government/party control and censorship some literary texts that contained "undesirable" information or allusions (e.g. to the Bible) were translated with numerous alterations and/or omissions (Klimovich, 2015).

Consequently, in case of conscious manipulation the manipulator is culture in the broad sense of this word (including customs 
and beliefs, social organization of a particular country or group, art, music, beliefs, attitudes, political culture, etc.) (Oxford Advanced Learners Dictionary, 2007, p. 373). Culture is one of the most important factors as customs, traditions, religion and political situation of the country of the target language determines the initiator's, as well as the translator's actions.

\section{Conclusion}

Thus, the personality of manipulator in translation is determined by the type of manipulation. When it concerns unconscious manipulation, the translator him/herself acts as a manipulator, distorting the text unintentionally, only due to ignorance or the lack of experience.
In those cases when texts were written with the intention to manipulate the readers the translator acts as unconscious manipulator as well, as he/she doesn't change the meaning of the texts and doesn't manipulate the readers directly. The readers are manipulated by the author.

When it concerns conscious manipulation the initiator of translation acts as the manipulator, determining translator's actions and/or controlling the result of translation. In some cases the initiator's, as well as translators' actions and motivation are determined by the existing political situation, social norms and intentions. Under these circumstances, culture itself acts as the manipulator, influencing the initiator's, the translator's, and even the author's actions.

\section{References}

Absattarov, R.B. Political Manipulation: Concept and Definition. Available at: http://www. rusnauka.com/12_KPSN_2012/Politologia/3_107760.doc.htm._Accessed 12.09.15.

Bassnett, S. \& Lefevere, A. Constructing Cultures: Essays on Literary Translation. Clevedon, Multilingual Matters Ltd, 2000. 143 p.

Braiker, H.B. How to Break The Cycle of Manipulation and Regain Control of Your Life. N.Y, McGraw-Hill Prof Med/Tech, 2004. 256 p.

Dukate, A. Manipulation as a Specific Phenomenon in Translation and Interpreting. (Available at: http://www3.acadlib.lv/greydoc/Dukates_disertacija/Dukate_ang.doc - Published 2007. Accessed 15.07.2014). $32 \mathrm{p}$.

Farahzad, F. A Gestalt Approach to Text Manipulation in Translation. (Available at: http://files. eric.ed.gov/fulltext/ED429437.pdf - Published 1998. Accessed 25.08.2014). 14 p.

Hermans, T. The Manipulation of Literature: Studies in Literary Translation. Croom Helm, 1985. $249 \mathrm{p}$.

Holiday, R. What is Media Manipulation? - A Definition and Explanation. The Forbes. (Available at: http://www.forbes.com/sites/ryanholiday/2012/07/16/what-is-media- manipulation-a-definitionand-explanation/. Accessed 12.09.2015).

Klimovich, N.V. (2015). Manipulation in Translation (Exemplified by the International Elements' Translation). J. of Siberian Federal University. Humanities and Social Sciences, 8(2), 244-151.

Kornaukhova, N.G. (2011). Translation vs. Version: Types of Manipulation in Literary Translation ["Perevod vs. versiia: vidy manipuliatsii v khudozhestvennom perevode"]. Bulletin of Irkutsk State Linguistic University, 176-183.

Kornaukhova, N.G. Manipulation in Translation: Myth or Reality? ["Manipuliatsiia v perevode: mif ili real'nost'?"]. Translation in the Era of Post-Modernism: Scientific Papers Collection. Irkutsk, ISLU, 2009, p. 36-43. 
Kramina, A. Translation as Manipulation: Causes and Consequences, Opinions and Attitudes (Available at: http://www.kalbos.lt/zurnalai/06_numeris/06.pdf - Published 2004. Accessed 13.09.2014). 5 p.

Kuhiwczak, P. The Troubled Identity of Literary Translation. Translation Today: Trends and Perspectives. Ed. by Gunilla Anderman and Margaret Rogers. Beijing, Foreign Language Teaching and Research Press, 2006, p. 112-124.

Kunitsyna, E.Iu. Shakespeare - Play - Translation [Shekspir - Igra - Perevod]. Irktsk, ISLU, 2009. $384 \mathrm{p}$.

Landers, C. E. Literary Translation: A Practical Guide. Shanghai Foreign Language Education Press, 2001. 214 p.

Lefevere, A. Translation, Rewriting and Manipulation of Literary Fame. London; New York, Routledge, 1992. $170 \mathrm{p}$.

Longman Dictionary of Contemporary English. Pearson Education Limited, 2005. 1949 p.

Nord, C. Text Analysis in Translation. Theory, Methodology, and Didactic Application of a Model for Translation-Oriented Text Analysis. Beijing, Foreign Language Teaching and Research Press, 2006. $274 \mathrm{p}$.

Oxford Advanced Learners Dictionary. Oxford University Press, 2007. 1780 p.

Pym, A. Method in Translation History. Beijing, Foreign Language Teaching and Research Press, 2006. 220 p.

Simon, G. K. In Sheep's Clothing: Understanding and Dealing with Manipulative People. Little Rock, A.J. Christopher \& Co, 1996. 122 p.

Schiller, H. I. The Mind Managers. Boston, Beacon Press, 1973. 214 p.

Toury, G. In Search of a Theory of Translation. Tel Aviv University Press, 1980. 159 p.

\section{Личность манипулятора в переводе}

\section{Н.В. Климович}

Сибирский федеральный университет Россия, 660041, Красноярск, пр. Свободный, 79

Статья посвящена исследованию проблемы манипулящии в переводе. Исследуя причины манипуляции, автор предпринимает попьытку выяснить, кто и/или что влияет на манипуляцию в переводе. Основываясь на понятии «инициатор» и двух видах манипуляции в переводе, дается обоснование понятия «манипулятор» и определяется субъект|явление, сознательно или бессознательно влияющее на манипуляцию в переводе или определяющее ее.

Ключевые слова: инициатор, манипулятор, художественный текст, сознательная манипуляция, бессознательная манипуляция.

Научная специальность: 10.00.00 - филологические науки. 